This article was published in Colloid and Polymer Science, 293(11), 3167-3175, 2015

http://dx.doi.org/10.1007/s00396-015-3710-9

\title{
Synthesis and study of the complex formation of a cationic alkyl chain bola amino alcohol with DNA: In vitro transfection efficiency
}

Diana Paiva ${ }^{1}$, Thomas Markowski ${ }^{2}$, Bodo Dobner ${ }^{2}$, Gerald Brezesinski $^{3 *}$, Helmuth Möhwald ${ }^{3}$, Maria do Carmo Pereira ${ }^{1}$, Sandra Rocha $^{4 *}$

${ }^{1}$ LEPABE, Faculdade de Engenharia, Universidade do Porto, Rua Dr. Roberto Frias, 4200-465, Porto, Portugal

${ }^{2}$ Institute of Pharmacy, Martin Luther University Halle-Wittenberg, Wolfgang-Langenbeck-Str. 4, 06120 Halle (Saale), Germany

${ }^{3}$ Max Planck Institute of Colloids and Interfaces, Science Park Potsdam-Golm, 14476 Potsdam, Germany

${ }^{4}$ Biology and Biological Engineering, Chalmers University of Technology, Gothenburg SE41296, Sweden

*E-mail: brezesinski@mpikg.mpg.de; sandra.rocha@chalmers.se

\section{Abstract}

Recent studies point out that bolaamphiphiles can be used in non-viral gene therapy. Due to their bipolar character, they may span a membrane and thus stabilize or destabilize it, which could be relevant for DNA transfer across a biological membrane. Since there are only very few studies on bolaamphiphile application in DNA transfection, it is difficult to assess whether they will bring additional advantages to the class of non-viral vectors. A bolaamphiphile with a hydrophobic chain of 22 carbon atoms with trimethylammonium and hydroxyl groups at each end was synthesised (22-hydroxydocos-1-yl-N,N,N-trimethylammonium bromide). It has been shown that this bolaamphiphile can transfect the green fluorescent protein plasmid in cells if mixed with a cationic helper lipid. It can compete with standard cationic lipds in terms of transfection, but is at the same 
time less toxic. The potential of this class of molecules in gene delivery results from the fact that they will confer high stability to the DNA vector.

\section{Introduction}

In recent years, the research interest in non-viral gene transfection has gradually increased due to issues associated with the safety of viral vectors such as immune response and inflammation [1], activation of oncogenes and hindrance of the expression of tumor suppressor genes [2-4]. Beside these drawbacks, viral gene transfection is also expensive and has the additional limitation of the gene size: only small nucleic acid sequences can be transported by the modified viruses $[5,6]$. Nonviral vectors, which are polymer or lipid based, are safer, but have rather low transfection efficiency and lower stability. Thus, the research and development effort for non viral vectors is very much focused on the improvement of their transfection efficiency and stability. Bolaamphiphiles have two hydrophilic head groups linked by a hydrophobic spacer that can have one, two or three alkyl chains. These surface-active molecules can self-assemble in water, and form monolayer lipid membranes which have a higher packing density and are less permeable than lipid bilayer membranes [7,8]. Mixed with fatty acids and trimethylammonium amphiphiles, single-chain bolaamphiphiles increase the stability and encapsulation efficiency of vesicles [9]. The bolaamphiphiles have their origin in the lipids of archeaebacteria. Their membrane is formed by tetraether isoprenoid based bolaamphiphiles, rendering them resistant to high temperature and low $\mathrm{pH}[10]$. The prefix "bola" is associated to the shape of an old South American missile weapon that consists of two balls connected by a cord. There are only few molecules in nature with these properties, thus most bolaamphiphiles are synthesized chemically [11,12]. Bolaamphiphiles can be assembled into distinct structures, that could be used as gene carriers [13]. Yoshimura et al. investigated anchored and cationic bolaamphiphiles with steroids, lithocholic acid and cholestane as the hydrophobic part of the molecule [14]. This approach was based on DC-cholesterol, which is an established transfection agent used in cationic liposomes [15,16]. Unsymmetric cationic 
bolaamphiphiles similar to archaebacterial lipids were prepared by the group of Benvegnu [17]. These compounds contain a C22 or C32 chain with a sugar moiety on one side and a quaternized glycinamide on the opposite side. The bolaamphiphile can be intercalated in lipid bilayer vesicles if the size of its hydrophobic part is close to twice of the size of the hydrophobic part of the lipid molecules [18]. Bolaamphiphiles can also acquire an U-shape to better blend with the bilayer [1921].

Réthoré et al. proposed diglycerol tetraether lipids with two quaternary glycine amid moieties at both ends, also called "archaeosomes", as gene vectors [22]. A more complex molecule containing a folic acid component connected via a polyethylene glycol chain with such an "archaesome" molecule was synthesized and characterized with regard to gene transfection [23]. The folate residue was introduced for targeting, since folate receptors are overexpressed by human tumor cells. These bola lipid derived transfecting agents exhibit also an enhanced membrane stability. Based on the synthesis and characterization of new bola compounds $[8,24]$ and their application as gene carrier $[25,26]$ this study was focused on the complexation behavior of simple long chain amino alcohol membranes with DNA. We report the synthesis of a new type of bola lipid, study its aggregation, transfection and cytotoxicity in combination with DNA.

The structure of compound BA is shown in Figure 1. A permanent positive charge was introduced by the use of a quaternary trimethylammono group. The other end contains the hydroxyl function as polar group. The synthesized molecule can self-assemble in water and form structures with crystal shape. The molecule was mixed with the cationic lipid DOTAP (Figure 1) to form stable vesicles with small sizes due to the two polar heads and the long carbon chain present in the bolaamphiphile [13].

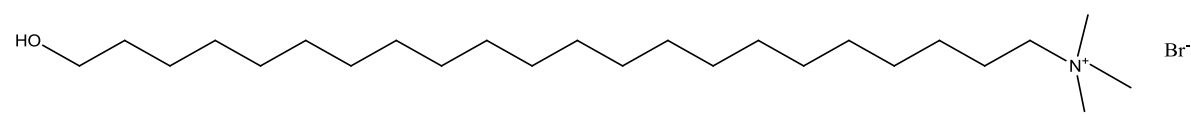




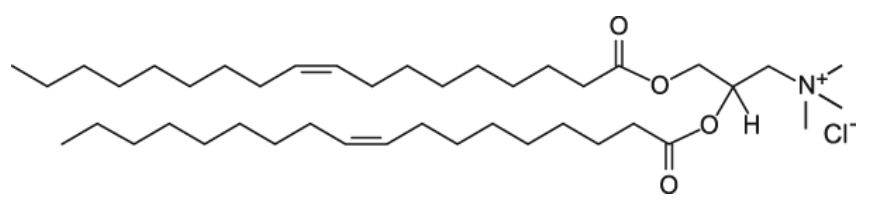

Figure 1: Chemical structures of 22-Hydroxydocos-1-yl-N,N,N-trimethylammonium bromide (BA, top) and 1,2-dioleoyl-3-trimethylammonium-propane (DOTAP, bottom).

\section{Materials and methods}

\section{Chemicals}

DOTAP (1,2-dioleoyl-3-trimethylammonium-propane, chloride salt, MW 698.542) and Rhod PE (1,2-dipalmitoyl-sn-glycero-3-phosphoethanolamine-N-(lissamine rhodamine B sulfonyl), ammonium salt, MW 1249.65) were purchased from Avanti Polar Lipids. Chloroform was acquired from Merck. All the other chemicals were supplied by Sigma-Aldrich. The solvents for the Grignard-reaction and for chromatography were dried and distilled before use. The green fluorescent protein (GFP) plasmid (pEGFP-N1, BD Biosciences Clontech) encoding for green fluorescent protein, hereafter designed as pDNA, was amplified and isolated with a PlasmidPrep Midi Flow kit (GE Healthcare) and the concentration and purity of pDNA were assessed using a NanoDrop 1000 (Thermo Scientific) apparatus. The deionized water was purified with a Milli-Q apparatus with the specific resistance of $18.2 \mathrm{M} \Omega \cdot \mathrm{cm}$. All solutions, except those containing DNA, were filtered through a $200 \mathrm{~nm}$ porous membrane.

\section{Synthesis}

2-(Docos-21-en-1-yloxy)tetrahydro-2H-pyrane (1): A Grignard-reagent was prepared from 0.11 mol (2.67 g) magnesium in $150 \mathrm{ml}$ dry THF under inert conditions by dropping $0.09 \mathrm{~mol}$ (20.96 g) 1-bromoundec-1-ene into the slurry of magnesium turnings at such a rate that the temperature was always between $40{ }^{\circ} \mathrm{C}$ and $50{ }^{\circ} \mathrm{C}$. Then the mixture was stirred for further $3 \mathrm{~h}$ at $50{ }^{\circ} \mathrm{C}$. After cooling to room temperature, the Grignard reagent was decanted under inert conditions from the magnesium residue. The magnesium deposit was washed with $30 \mathrm{ml}$ dry THF which was 
combined with the Grignard solution. The combined solutions were cooled down to $-5{ }^{\circ} \mathrm{C}$ under argon. Then, $0.059 \mathrm{~mol}$ (19.85 g) of 2-(11-bromoundec-1-yloxy)tetrahydro-2H-pyrane dissolved in $20 \mathrm{ml}$ dry THF were added at once followed by $20 \mathrm{ml}$ of a $0.1 \mathrm{M}$ solution of lithium tetrachlorocuprate in THF. The mixture was stirred for 3 hours at -5 to $0{ }^{\circ} \mathrm{C}$. The mixture was poured into $200 \mathrm{ml}$ ice-cold 5\% ammonia chloride solution, and the product was extracted three times with $100 \mathrm{ml}$ ether. The combined ethereal solutions were washed with brine and dried over sodium sulfate. After evaporation of the solvent, the crude compound $\mathbf{1}$ was purified using column chromatography with heptane/ether and ammonia $(0.1 \mathrm{ml} / 100 \mathrm{ml}$ eluent $)$ using gradient technique. Yield: 19.49 g (81\%), white waxy solid, mp: $33{ }^{\circ} \mathrm{C}$. ESI-MS: m/z $409.3(\mathrm{M}+\mathrm{H}), 432.4(\mathrm{M}+\mathrm{NaO})$. Calcd. for $\mathrm{C}_{27} \mathrm{H}_{52} \mathrm{O}_{2}$ : C, 79.35; H, 12.82. Found: C, 79.44; H, 12.71. ${ }^{1} \mathrm{H}-\mathrm{NMR}\left(\mathrm{CDCl}_{3}, 400 \mathrm{MHz}\right)$ : $\delta=1.23-1.38(\mathrm{~m}, 36 \mathrm{H}$, [chain] $), 1.45-1.88\left(\mathrm{~m}, 6 \mathrm{H},\left[-\mathrm{CH}_{2}-\mathrm{CH}_{2}-\mathrm{O}-\right.\right.$, ring $\left.]\right), 1.99-2.04\left(\mathrm{~m}, 2 \mathrm{H},\left[-\mathrm{CH}_{2}-\right.\right.$ $\mathrm{CH}=]), 3.32-3.40$ (m, 1H, [-HCH-O-]), 3.45-3.51 (m, 1H, [-HCH-O-]), 3.68-3.75 (m, 1H, [-HCHO-]), 3.83-3.89 (m, 1H, [-HCH-O-]), 4.55-4.57 (t, 1H, [-O-CH-O-]), 4.95 (q, 2H, [= $\left.\left.\mathrm{CH}_{2}\right]\right), 5.75-$ $5.83(\mathrm{~m}, 1 \mathrm{H},[-\mathrm{CH}=]) \mathrm{ppm}$.

22-(Tetrahydro-2H-pyran-2-yloxy)docosanol (2): To a solution of $0.04 \mathrm{~mol}(16.32 \mathrm{~g})$ of compound 1 in $120 \mathrm{ml}$ dry THF $80 \mathrm{ml}$ of a $0.5 \mathrm{M}$ 9-BBN solution in THF were added dropwise for $20 \mathrm{~min}$ via a syringe under stirring. The mixture was stirred for further $6 \mathrm{~h}$ at room temperature. At $20{ }^{\circ} \mathrm{C}, 28 \mathrm{ml}$ ethanol, $8.48 \mathrm{ml} \mathrm{NaOH}(6 \mathrm{M})$ and $17 \mathrm{ml} \mathrm{H}_{2} \mathrm{O}_{2}(30 \%)$ were dropped successively into the mixture, where the temperature was raised to $50{ }^{\circ} \mathrm{C}$. The solution was stirred further for $1 \mathrm{~h}$ at $50{ }^{\circ} \mathrm{C}$. After cooling down to room temperature, $\mathrm{K}_{2} \mathrm{CO}_{3}$ was added, and the organic phase was separated. The organic layer was then dried over $\mathrm{K}_{2} \mathrm{CO}_{3}$ and evaporated. The crude product was purified by column chromatography using $\mathrm{CHCl}_{3} /$ ether and TEA $(0.1 \mathrm{ml} / 100 \mathrm{ml}$ eluent $)$ and the gradient technique. Yield: $15.72 \mathrm{~g}(92 \%)$, white waxy solid, mp: $55-56{ }^{\circ} \mathrm{C}$. ESI-MS: $\mathrm{m} / \mathrm{z} 427.3$ $(\mathrm{M}+\mathrm{H}), 449.1(\mathrm{M}+\mathrm{Na})$. Calcd. for $\mathrm{C}_{27} \mathrm{H}_{54} \mathrm{O}_{3}: \mathrm{C}, 76.00 ; \mathrm{H}, 12.76$. Found: C, 75.81; H, 12.52. ${ }^{1} \mathrm{H}-$ NMR ( $\left.\mathrm{CDCl}_{3}, 400 \mathrm{MHz}\right): \delta=1.21-1.40\left(\mathrm{~m}, 38 \mathrm{H}\right.$, [chain]), 1.44-1.82 (m, 8H, [-CH2- $\left.\left.\mathrm{CH}_{2}-\mathrm{O}-\right]\right)$, 
3.34-3.40 (m, 1H, [-HCH-O-]), 3.47-3.52 (m,1H, [-HCH-O-]), 3.64 (t, 2H, [-CH $\left.\left.{ }_{2} \mathrm{OH}\right]\right), 3.68-3,74$ (m, 1H, [-HCH-O-]), 3.82-3.889 (m, 1H, [-HCH-O-]), 4.56 (t, 1H, [-OCH-O]) ppm.

2-(22-Bromdocosan-1-yloxy)tetrahydro-2H-pyrane (3): $0.03 \mathrm{~mol}(12.82 \mathrm{~g})$ of the alcohol 2 were dissolved in $60 \mathrm{ml}$ dry chloroform. $0.036 \mathrm{~mol}(5.0 \mathrm{ml})$ TEA and $20 \mathrm{mg}$ DMAP were added to the solution. After the mixture was cooled down to $0{ }^{\circ} \mathrm{C}$, a cooled solution of $0.036 \mathrm{~mol}(2.73$ ml) methansulfonic acid chloride was added at such a rate that the temperature remained at $0{ }^{\circ} \mathrm{C}$. The mixture was stirred for another hour at that temperature and for further $3 \mathrm{~h}$ at room temperature. $0.012 \mathrm{~mol}(1.6 \mathrm{ml})$ TEA in $20 \mathrm{ml}$ water were dropped into the solution. The organic layer was separated, washed with $20 \mathrm{ml}$ water and dried with sodium sulfate. After evaporation of the solvent, the residue was dried over $\mathrm{P}_{2} \mathrm{O}_{5}$ in vacuum. The crude methane sulfonic acid ester was dissolved in $40 \mathrm{ml}$ dry acetone. After addition of $0.0875 \mathrm{~mol}$ (7.6 g) lithium bromide, the mixture was stirred for $3 \mathrm{~h}$ under reflux. The mixture was cooled down, the solvent was removed to half of the total volume and the residue was poured into $100 \mathrm{ml}$ cold water. The mixture was extracted two times with $100 \mathrm{ml}$ ether and the collected organic layers were washed with $100 \mathrm{ml}$ water. After drying the solution over sodium sulphate, the solvent was evaporated and the residue was purified using column chromatography with heptane/ether-gradient and $0.1 \mathrm{ml}$ TEA/100 ml eluent. Yield: 12,42 g (84,6 \%), white pasty solid, EI-MS (m/z): $489[\mathrm{M}]^{+} .{ }^{1} \mathrm{H}-\mathrm{NMR}\left(\mathrm{CHCl}_{3}, 400 \mathrm{MHz}\right): \delta=$ 1.18-1-36 (m, 36H, [chain]), 1,35-1.6 (m, 6H, [- $\mathrm{CH}_{2}-\mathrm{CH}_{2}-\mathrm{CH}_{2}-\mathrm{CH}$,ring]), 1.66-1.86 (m, 4H, [$\left.\mathrm{CH}_{2}-\mathrm{CH}_{2}-\mathrm{O}-\mathrm{CH}\right]$, [Br- $\left.\left.\mathrm{CH}_{2}-\mathrm{CH}_{2}-\right]\right), 3.36-3.42$ (m, 2H, [- $\left.\left.\mathrm{CH}_{2}-\mathrm{CH}_{2}-\mathrm{O}-\mathrm{CH}\right]\right), 3.49-2.53$ (m, 2H, [Br$\left.\left.\mathrm{CH}_{2}-\mathrm{CH}_{2}-\right]\right), 3.66-3.76$ (m, 2H, [-CH-O-CH $2_{2}^{-}$, ring), 4.47-4.51 (m, 1H, [O-CH-O]) ppm.

\section{2-(Tetrahydro-2H-pyran-2yloxy)docos-1-yl-N,N,N-trimethylammonium bromide (4): 5} mmol (2.44 g) of compound 3 were dissolved in $20 \mathrm{ml}$ chloroform/acetonitrile (1:1). $50 \mathrm{mmol}$ of an alcoholic solution of trimethyl amine (33\%) was added, and the mixture was heated to $50{ }^{\circ} \mathrm{C}$ in a closed vessel for $10 \mathrm{~h}$. Afterwards, the mixture was kept for several days at room temperature 
(dc control). The solvent and the excess of amine were evaporated and the crude substance was purified using mplc or by column chromatography with chloroform/methanol/water gradient technique. Yield: 2.01g (73.4\%), white solid, mp: 160-162 ${ }^{\circ} \mathrm{C}$. ESI-MS (m/z): 468.7 [M-Br] $]^{+}$ HR-MS (m/z) calcd.: 468.4781[M-Br $]^{+}$. Found: 468.4759. Elemental analysis calcd. for $\mathrm{C}_{30} \mathrm{H}_{62} \mathrm{BrNO}_{2}: \mathrm{C}, 65.64 ; \mathrm{H}, 11.39 ; \mathrm{N}, 2.55 ; \mathrm{Br}, 14.56$. Found: C, 65.6; H, 11.34; N, 2.46; Br, 14.8. ${ }^{1} \mathrm{H}-\mathrm{NMR}\left(\mathrm{CDCl}_{3}, 400 \mathrm{MHz}\right): \delta=1.18-1.34\left(\mathrm{~m}, 34 \mathrm{H},\left[-\left(\mathrm{CH}_{2}\right)_{18^{-}}\right]\right), 1.48-1.81\left(\mathrm{~m}, 10 \mathrm{H},\left[-\left(\mathrm{CH}_{2}\right)_{3^{-}}\right.\right.$ CH-O-CH$\left.\left.\left.{ }_{2}-\mathrm{CH}_{2}-\right],\left[-\mathrm{CH}_{2}-\mathrm{CH}_{2}-\mathrm{N}\left(\mathrm{CH}_{3}\right)_{3}\right]\right)\right), 3.33-3.39$ (m, 1H, [-CH-O-CH$\left.\left.{ }_{2}-\right]\right), 3.45$ (s, 9H, [$\left.\left.\mathrm{N}\left(\mathrm{CH}_{3}\right)_{3}\right]\right), 3.48-3.55\left(\mathrm{~m}, 1 \mathrm{H},\left[-\mathrm{CH}-\mathrm{O}-\mathrm{CH}_{2}-\right]\right.$ and $\left.2 \mathrm{H}\left[-\mathrm{CH}_{2}-\mathrm{N}\left(\mathrm{CH}_{3}\right)_{3}\right]\right), 3.68-3.73(\mathrm{~m}, 1 \mathrm{H},[-\mathrm{CH}-$ $\left.\left.\mathrm{O}-\mathrm{CH}_{2}-\right]\right), 3.82-3.85$ (m, 1H, [-CH-O-CH $\left.\left.2-\right]\right), 4.54-4,56$ (m, 1H, [-CH2-O-CH-]) ppm. ${ }^{13} \mathrm{C}-\mathrm{NMR}$ $\left(\mathrm{CDCl}_{3}, 100 \mathrm{MHz}\right): \delta=19.7-29.74$ [chain], 30.78 [-O-CH-CH2-], 53.32 [-N(CH3)3], 62.3 [- $\mathrm{CH}_{2}-$ O-CH], 66.99 [CH-O-CH 2$], 67.65$ [- $\left.\mathrm{CH}_{2}-\mathrm{N}\left(\mathrm{CH}_{3}\right)_{3}\right], 98.79$ [-O-CH-O-] ppm.

22-Hydroxydocos-1-yl-N,N,N-trimethylammonium bromide (BA): 1 mmol (0.54 g) of compound 4 and $10 \mathrm{mg}$ p-toluensulfonic acid were dissolved in $50 \mathrm{ml}$ methanol. The mixture was heated for $3 \mathrm{~h}$ under reflux. The solvent was then removed to half of the volume and $50 \mathrm{ml}$ water were added. The mixture was extracted three times with $50 \mathrm{ml}$ chloroform. The collected organic phases were dried (sodium sulphate), and the solvent was removed in vacuum. The crude compound BA was purified using column chromatography or mplc with chloroform/methanol/ammonia and gradient-technique. Yield: $0.27 \mathrm{~g}(58 \%)$, white solid, mp:154$157^{\circ}$ C.ESI-MS (m/z): 384.6 [M-Br] $]^{+}$. HR-Ms (m/z) calcd.: 384.4205 [M-Br] $]^{+}$. Found: 384.4195. ${ }^{1} \mathrm{H}-\mathrm{NMR}\left(\mathrm{CDCl}_{3}, 400 \mathrm{MHz}\right): \delta=0.97-1.16\left(\mathrm{~m}, 36 \mathrm{H},\left[-\left(\mathrm{CH}_{2}\right)^{18}-\right]\right), 1.29-1.32\left(\mathrm{~m}, 2 \mathrm{H},\left[\mathrm{HO}-\mathrm{CH}_{2}-\right.\right.$ $\left.\mathrm{CH}_{2}-\right), 1.50-1.56\left(\mathrm{~m}, 2 \mathrm{H},\left[-\mathrm{CH}_{2}-\mathrm{CH}_{2}-\mathrm{N}\left(\mathrm{CH}_{3}\right)_{3}\right]\right), 2.92\left(\mathrm{~s}, 9 \mathrm{H},\left[-\mathrm{N}\left(\mathrm{CH}_{3}\right)_{3}\right]\right), 3.07-3.12(\mathrm{~m}, 3 \mathrm{H}$, [HO$\left.\left.\mathrm{CH}_{2}-\right],\left[-\mathrm{CH}_{2}-\mathrm{N}\left(\mathrm{CH}_{3}\right)_{3}\right]\right), 3.31-3.35\left(\mathrm{t}, \mathrm{J}=6.6 \mathrm{~Hz}, 2 \mathrm{H},\left[\mathrm{HO}-\mathrm{CH}_{2}-\right]\right) \mathrm{ppm}$.

Purification. The compounds were purified using column chromatography and mplc. The ${ }^{1} \mathrm{H}$ and ${ }^{13} \mathrm{C}$ NMR-spectra were recorded with a Varian Gemini at 400 and $100 \mathrm{MHz}$, respectively. The 
solvent was used as internal standard. The EI-mass spectra were obtained with an AMD 402 (70eV) (Fa. AMD Intecta GmbH, Harpstedt). ESI-MS was performed using a Finnigan MAT 710C. For the high resolution mass spectra a Q-TOF 2 (Waters/Micromass, Manchester, UK) was used.

\section{Preparation of Liposomes}

Liposomes were prepared by the thin lipid film hydration method. Briefly, the appropriate lipid mixture (BA:DOTAP) at different molar ratios $(1: 1,1: 5$ and 1:10) was dissolved in chloroform, which was then evaporated under $\mathrm{N}_{2}$ flow. The lipid film was hydrated with $1 \mathrm{~mL}$ of $10 \mathrm{mM}$ Hepes buffer at $\mathrm{pH} 7.4$ (ionic strength $0.00325 \mathrm{M}$ ). The suspension was vortexed for 15 minutes, sonicated for $15 \mathrm{~min}$ at $60{ }^{\circ} \mathrm{C}$ and extruded at $60{ }^{\circ} \mathrm{C}$ through Whatman filters of decreasing pore sizes (down to $100 \mathrm{~nm}$ pore size membranes) using a Lipex pressure extruder apparatus (Northern Lipids Inc.). The total lipid concentration was $1 \mathrm{mM}$.

\section{Dynamic light scattering and zeta potential}

The hydrodynamic diameter and the zeta potential of the liposomes and lipoplexes were measured at room temperature with a Malvern Zetasizer Nano series instrument by, respectively, dynamic light scattering (DLS) and laser Doppler velocimetry. The results were averaged from three measurements for each sample and were obtained for at least three independent procedures of sample preparation. The final concentration of liposomes was $0.1 \mathrm{mg} / \mathrm{mL}$, and the concentration of pDNA was $0.01 \mathrm{mg} / \mathrm{mL}$.

\section{Morphology studies}

Transmission Electron Microscopy (TEM) and Confocal Laser Scanning Microscopy (CLSM) were used for the characterization of the structures formed by the bolaamphiphile BA alone. For the TEM (Jeol JEM-1400, JEOL) analysis, a drop of the suspension was placed on copper grids (Formvar/carbon on 400 mesh - Agar) and stained with 2\%(w/v) uranyl acetate. For CLSM 
imaging (Leica TCS SP5 II, Leica Microsystems), the bolaamphiphile solution was previously mixed with $0.2 \%(\mathrm{w} / \mathrm{w})$ of Rhod PE lipid (fluorescent marker) in chloroform, which was evaporated and the film was hydrated, in order to mix properly the two lipids in solution.

\section{In vitro transfection studies}

The gene transfer and transgene expression after cellular transfection was monitored using pDNA encoded with GFP. The HEK 293 cell line was used in this study and was grown in Minimum Essential Medium (Lonza), supplemented with 10\% (v/v) heat inactivated fetal bovine serum (FBS - Gibco), 2 mM L-Glutamine (Lonza), 100 U Penicillin/Streptomycin (Gibco) and 1\% MEM nonessential amino acid solution (Sigma). Cells were cultured in a humidified $5 \% \mathrm{CO}_{2}$ atmosphere at $37{ }^{\circ} \mathrm{C}$. For transfection studies cells were seeded at approximately $70 \%$ confluence in 12 -well tissue culture plates $24 \mathrm{~h}$ before the experiments. Before transfection, growth medium was removed and cells were washed twice with PBS, pH 7.4. Liposome-pDNA complexes were prepared by adding equal volumes of pDNA solution at $0.01 \mathrm{mg} / \mathrm{mL}$ to the liposome suspension. The lipid:pDNA ratio was 10:1 (w:w), corresponding to a N:P ratio of 5 for BA:DOTAP liposomes (charge ratio between the cationic groups (amine) of the liposome and the anionic groups (phosphate) of the pDNA) [27-29]. DNA solution was added dropwise to the liposomes, and the mixture was kept under magnetic stirring for at least 15 minutes. Cells were then incubated with $200 \mu \mathrm{L}$ of lipoplexes prepared with liposomes and pDNA in OPTI-MEM (Gibco). The final concentration of pDNA was $2 \mu \mathrm{g} /$ well. The negative control corresponded to cells treated with liposomes without pDNA. After $5 \mathrm{~h}$, the medium was replaced by fresh growth medium, and transfection was assessed after $48 \mathrm{~h}$ incubation time by flow cytometry (FACS Canto II, BD Biosciences). Twenty thousand events were measured for each sample. Experimental data were statistically analyzed applying one-way analysis of variance (ANOVA) following the Tukey test approach. Microscopy images of transfected cells were obtained using the CLSM. 


\section{Results and Discussion}

\section{Synthesis}

For the preparation of the 22-hydroxy-docos-1-yl-N,N,N-trimethylammonio bromide (BA) the copper-catalyzed Grignard coupling of suitable building blocks was used [24,30]. Thus, the commercially available 11-bromoundec-1-ene was transformed into the corresponding Grignard reagent using THF as solvent with respect to the following coupling step. After separation of the excess magnesium the Grignard-reagent was converted into the 2-(docos-21-en-1yloxy)tetrahydro-2H-pyrane (1) by reaction with 2-(11-bromoundecane-1-yloxy)tetrahydro-2Hpyrane with $0.1 \mathrm{M}$ solution of dilithium tetrachlorocuprate below $0{ }^{\circ} \mathrm{C}$. The terminal double bond was transformed into the primary hydroxyl group per hydroboration reaction with 9-BBN followed by common oxidation with hydrogen peroxide. Starting from 2 the introduction of the bromine atom was realized in two steps. First of all the hydroxyl function was converted to the methane sulfonic acid ester using the corresponding acid chloride. The sulfonic ester moiety was then replaced by bromine with dry lithium bromide in acetone. For the introduction of the trimethylammonio group an ethanolic solution of trimethylamine and compound $\mathbf{3}$ were heated in a closed vessel until the quaternation was complete. The final compound was delivered under mild conditions with pyridinumtosylate in methanol under reflux.

\section{Bolaamphiphile self-assembled structure}

Attempts of extruding samples containing only compound BA were not successful, even at high temperatures $\left(80{ }^{\circ} \mathrm{C}\right)$. The characterization of the structure by CLSM and TEM analysis shows that BA forms microstructures, some of which present a crystal shape (Figure 2). 

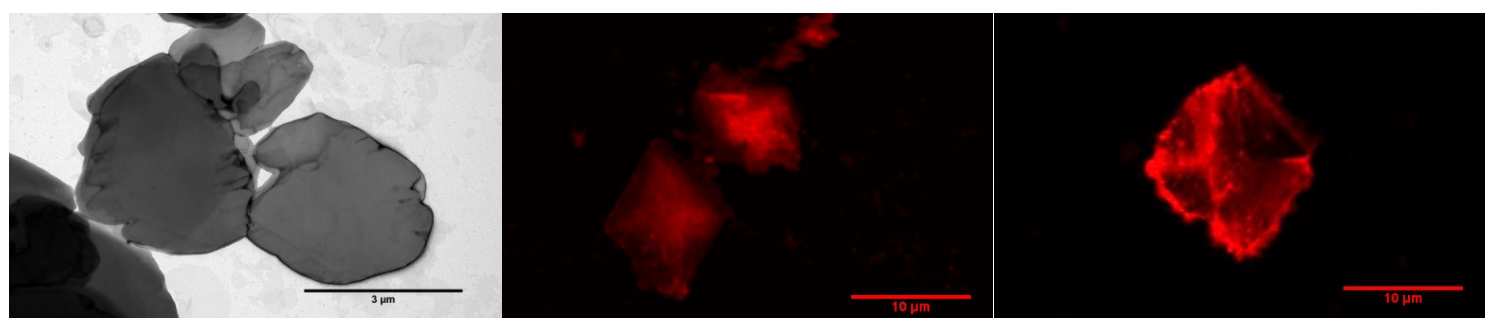

Figure 2: Self-assembled bolaamphiphile BA structures observed by TEM (left) and CLSM (right). Scale bar is, respectively, 3 and $10 \mu \mathrm{m}$.

Crystalline structures are expected, if the size of the two polar groups is not too different. For instance, they could assemble into a bilayer, where the $\mathrm{OH}$ groups will be oriented towards the inner space and the N- groups to the outer space (Figure 3.a). They may also form a mixed orientation where an $\mathrm{OH}$ group and a $\mathrm{N}$ - group will be in the inner space, as represented in Figure 3.b [7].

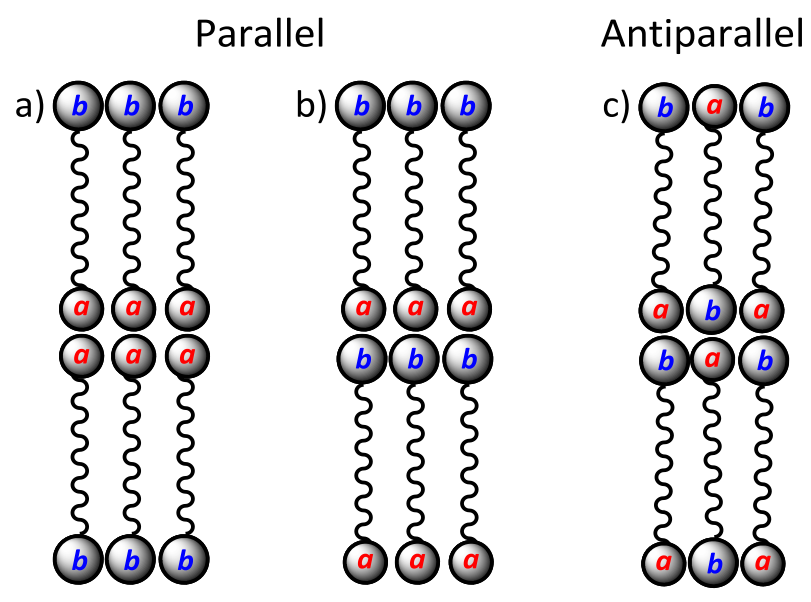

Figure 3: Schematic representation of possible arrangements of asymmetric bolamphiphiles in crystals: a) parallel $a, a$; b) parallel $a, b ; c$ ) antiparallel $a, b$ and $b, a$ (adapted from [7]).

Previous works report that these amphiphiles self-assemble into small nanoparticles (50-100 nm) $[31,29]$, suggesting the formation of an asymmetric monolayer, which was confirmed by Langmuir monolayer studies and Grazing incidence X-Ray diffraction [19,32-34]. However, these structures are influenced by the number of carbons in the hydrophobic part of the molecule as well as the forces present in the hydrophilic part. The hydrophobic tail of compound BA has no double bonds, which would allow the formation of monolayer vesicles, where the OH-end group would be 
directed to the inside of the vesicle and the $\mathrm{N}$ group to the outside. Due to its long hydrocarbon chain, BA can arrange itself in a U-shape, reported in the literature for similar molecules $[35,36]$. In this case, a bilayer would be formed and its structure could be more rigid, generating bigger particles that cannot be extruded. Mixing the compound BA with other lipids at appropriate ratios resulted in the formation of large unilamellar vesicles (LUV), where the bolaamphiphile BA was intercalated in the lipid bilayer. BA was mixed with a well-known cationic lipid commonly used in gene delivery [37], DOTAP, at BA:DOTAP molar ratios of 1:1, 1:5 and 1:10. For the ratio 1:1, the size of the structures was smaller than that obtained for BA alone (Figure 4a), but extrusion of the sample was still not possible. At the molar ratios of 1:5 and 1:10, BA:DOTAP vesicles were extruded, and it was possible to obtain large unilamellar vesicles using filters with a pore size of $100 \mathrm{~nm}$. Vesicles prepared with BA:DOTAP (1:5 mol:mol) were used for in vitro cell culture studies, and the results were compared with those obtained for DOTAP liposomes. In the literature, mixtures of bolaamphiphiles with other lipids, such as cholesterol [38] and DOPE [29], have been reported mainly to stabilize the liposomes within the complexes formed with pDNA. Since the bolaamphiphile BA does not self-assemble into small vesicles, we propose the use of this molecule as a helper lipid to increase the stability and the transfection efficacy of lipid bilayer vesicles. BA was thus included into DOTAP vesicles. The zeta potential of BA:DOTAP (1:5 mol:mol) vesicles is slightly lower than that of DOPAP vesicles (Figure 4b), which indicates a different distribution of the positive charges at the surface of the vesicles. 

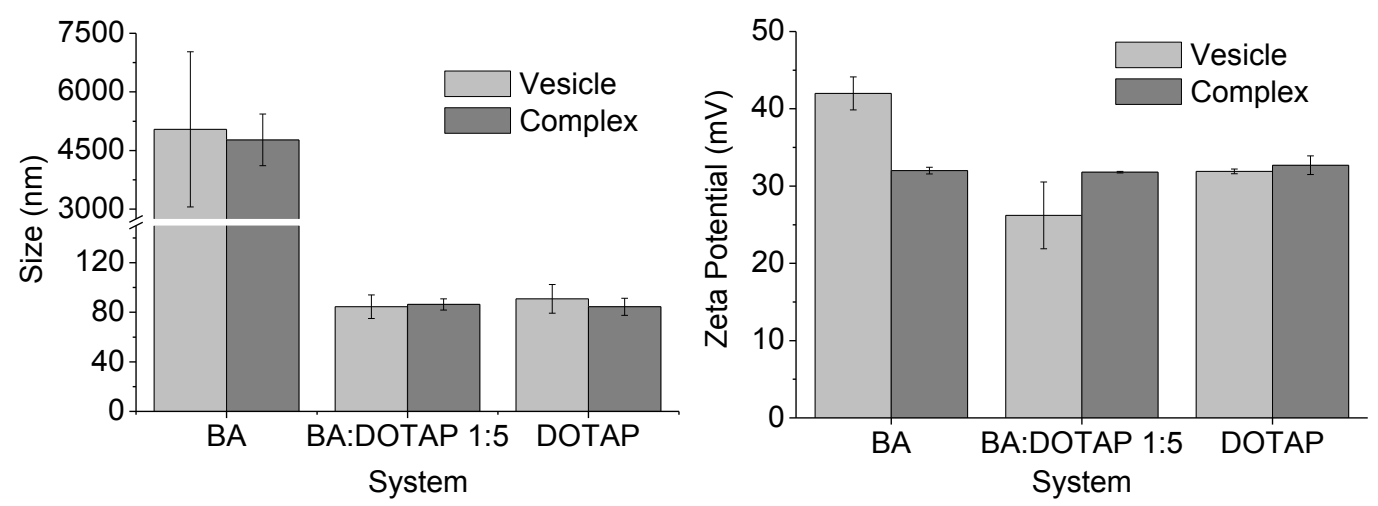

Figure 4: (a) Hydrodynamic diameter of vesicles of BA, DOTAP and their mixture at a ratio of 1:5 and (b) zeta potential values before and after the formation of a complex with DNA.

The complex formation with DNA was obtained at the ratio of lipid:pDNA 10:1 (w:w). The zeta potential values were about $32 \mathrm{mV}$ for all the pDNA:vesicle complexes (lipoplexes) (Figure 4). The size measurements of the lipoplexes reveal values similar to those obtained for the liposomes alone, however, the pDNA has an effect on the population distribution, as it seems to reduce the polydispersity index (PdI) of the sample. The parameters measured here indicate that all lipoplexes are stable and have a positive charge, which is a desirable condition for cell transfections studies.

\section{Cell transfection studies}

The transfection efficiency of the lipoplexes was evaluated using the HEK 293 cell line, a human embryonic kidney derived cell line. Cells were transfected with plasmid DNA (pDNA) encoding green fluorescent protein (GFP). Flow cytometry analysis revealed that GFP expression was induced similarly by DOTAP/pDNA and BA:DOTAP/pDNA (Figure 5A). Naked pDNA did not transfect cells (Figure 5B1).

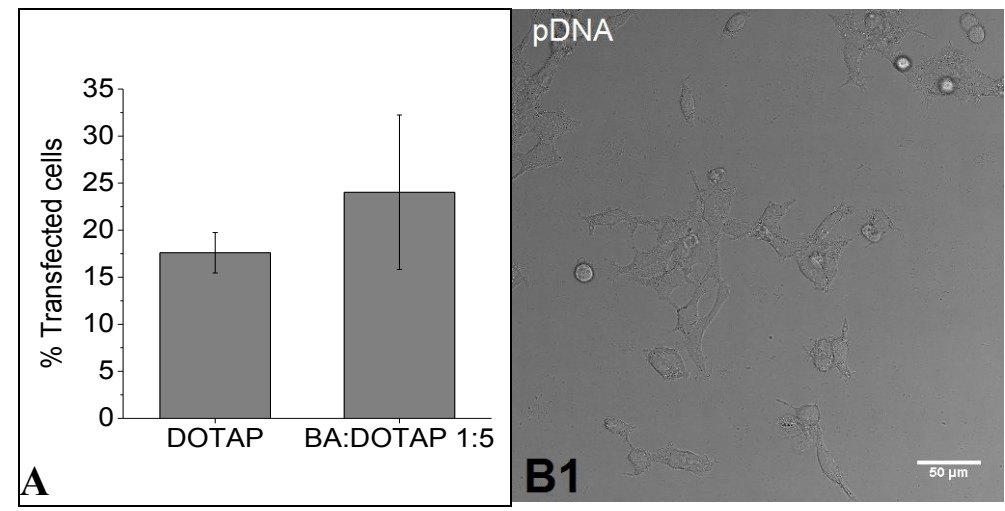




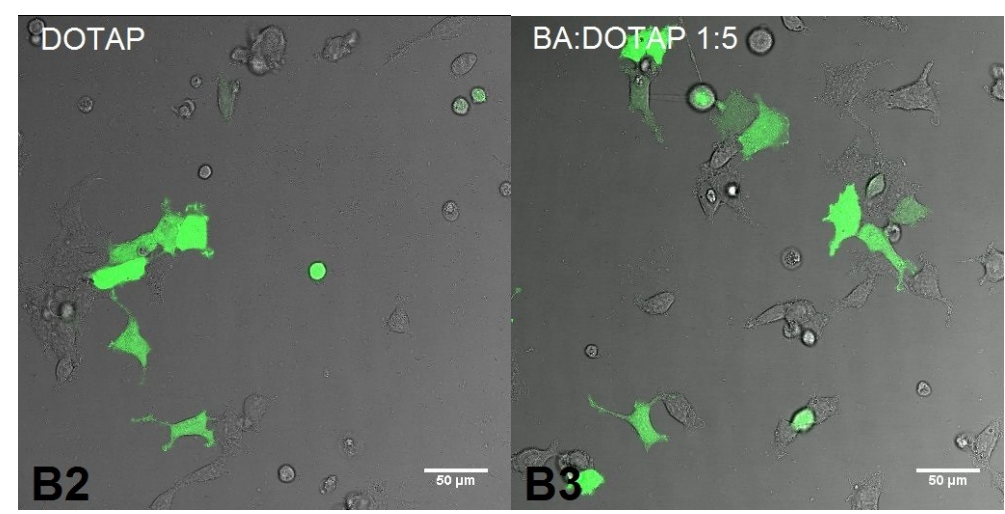

Figure 5: Transfection of the HEK cell line with green fluorescent protein (GFP) plasmid ( $p D N A)$ at a 10:1 L/D ratio: (A) cytometry analysis of transfection levels for DOTAP and BA:DOTAP 1:5 systems. Results are expressed as mean \pm S.D. $(n=3)$. (B) Illustrative confocal images of GFP expression when transfected with naked pDNA (B1), DOTAP (B2) and BA:DOTAP 1:5 (B3). The scale bar is $50 \mu \mathrm{m}$.

DOTAP has been proven to be an efficient and widely used system to complex, deliver and transfect DNA into, for example, human hematopoietic stem cells [39] and cervical cancer cells [40]. Combined with other lipids, such as cholesterol, DOTAP showed to be efficient in transporting genetic material in vivo [41-44]. Our results demonstrate that BA mixed with DOTAP at the molar ratio of 1:5 has the potential of being used as a helper lipid in vectors for pDNA delivery, evidenced by the positive results obtained with respect to the DOTAP system. In all cell trials, the BA:DOTAP system achieved higher values than pure DOTAP ,although according to the statistical analysis, they are not significantly different at the 0.05 level, indicating that both systems have a similar ability to transfect cells. The cytometry technique and confocal analysis, however, showed that DOTAP lipoplexes cause more cellular dead than BA:DOTAP lipoplexes, indicating that the latter system is less cytotoxic.

\section{Conclusions}

The properties associated to bolaamphiphiles are very promising with respect to application as delivery systems and as bio sensors [45]. Concerning the delivery of drugs/ DNA, the formation of nanoparticles, vesicles or small structures is desirable. As shown here, not all bolaamphiphiles can assemble as vesicles or other structures in the nanometer size range. This might be related to 
the presence of a single alkyl chain in the bola-molecule. In a lipid membrane, the bolaamphiphile can extend completely across the membrane or form a U-shape conformation in a single membrane leaflet, depending on the length and flexibility of the hydrophobic chain. The bolaamphiphile considered here can in principle adopt both conformations: Either fully extended in a DOTAP bilayer with a thickness of approximately $3.7 \mathrm{~nm}$ [46] (the monomolecular layer of long alkyl monofunctional silanes (docosyl C22) has an average thicknesses of $3.5 \mathrm{~nm}$ [47]) or U-shape, as single-chain bolaamphiphiles form U-shapes at the air-water interface [35]. The mixed system BA:DOTAP formed stable complexes with DNA and the transfection efficiencies were similar or better than those of the pure DOTAP system. An important aspect was also the decreased toxicity of the BA:DOTAP-DNA complexes. We thus propose vesicles that combine a bolaamphiphile with cationic lipids to form stable and positively charged liposomes capable of compacting efficiently genetic material by electrostatic interactions.

\section{Acknowledgements}

This work was supported by FCT and FEDER through COMPETE (PTDC/QUIBIQ/102827/2008 and PTDC/QUI-BIQ/118076/2010) and by the FCT/MEC with national funds and when applicable co-funded by FEDER in the scope of the P2020 Partnership Agreement (Project UID/EQU/00511/2013-LEPABE). D. Paiva thanks FCT for a PhD fellowship (SFRH/BD/45384/2008).

\section{References}

1. Hollon T (2000) NIH researchers receive cut-price BRCA test. Nature medicine 6 (6):610. doi:10.1038/76149

2. Woods N-B, Muessig A, Schmidt M, Flygare J, Olsson K, Salmon P, Trono D, von Kalle C, Karlsson S (2003) Lentiviral vector transduction of NOD/SCID repopulating cells results in multiple vector integrations per transduced cell: risk of insertional mutagenesis. Blood 101 (4):1284-1289. doi:10.1182/blood-200207-2238 
3. Schröder ARW, Shinn P, Chen H, Berry C, Ecker JR, Bushman F (2002) HIV-1 Integration in the Human Genome Favors Active Genes and Local Hotspots. Cell 110 (4):521-529. doi:http://dx.doi.org/10.1016/S0092-8674(02)00864-4

4. Li Z, Düllmann J, Schiedlmeier B, Schmidt M, von Kalle C, Meyer J, Forster M, Stocking C, Wahlers A, Frank O, Ostertag W, Kühlcke K, Eckert H-G, Fehse B, Baum C (2002) Murine Leukemia Induced by Retroviral Gene Marking. Science 296 (5567):497. doi:10.1126/science.1068893

5. Saraswat P, Soni RR, Bhandari A, Nagori BP (2009) DNA as therapeutics; An update. Indian Journal of Pharmaceutical Sciences 71 (5):488-498

6. Kay MA, Glorioso JC, Naldini L (2001) Viral vectors for gene therapy: the art of turning infectious agents into vehicles of therapeutics. Nature medicine 7 (1):33-40. doi:10.1038/83324

7. Fuhrhop J-H, Wang $T$ (2004) Bolaamphiphiles. Chemical Reviews 104 (6):2901-2938. doi:10.1021/cr030602b

8. Köhler K, Förster G, Hauser A, Dobner B, Heiser UF, Ziethe F, Richter W, Steiniger F, Drechsler M, Stettin H, Blume A (2004) Self-Assembly in a Bipolar Phosphocholine-Water System: The Formation of Nanofibers and Hydrogels. Angewandte Chemie International Edition 43 (2):245-247. doi:10.1002/anie.200351731

9. Caschera F, de la Serna JB, Löffler PMG, Rasmussen TE, Hanczyc MM, Bagatolli LA, Monnard PA (2011) Stable Vesicles Composed of Monocarboxylic or Dicarboxylic Fatty Acids and Trimethylammonium Amphiphiles. Langmuir 27 (23):14078-14090. doi:10.1021/la203057b

10. Fan Q, Relini A, Cassinadri D, Gambacorta A, Gliozzi A (1995) Stability against temperature and external agents of vesicles composed of archael bolaform lipids and egg PC. Biochimica et biophysica acta $1240(1): 83-88$

11. Fuhrhop JH, Fritsch D (1986) Bolaamphiphiles form ultrathin, porous and unsymmetric monolayer lipid membranes. Accounts of Chemical Research 19 (5):130-137. doi:10.1021/ar00125a002

12. Baek K, Kim Y, Kim H, Yoon M, Hwang I, Ko YH, Kim K (2010) Unconventional U-shaped conformation of a bolaamphiphile embedded in a synthetic host. Chemical Communications 46 (23):40914093

13. Jain N, Arntz Y, Goldschmidt Vr, Duportail G, Mély Y, Klymchenko AS (2010) New Unsymmetrical Bolaamphiphiles: Synthesis, Assembly with DNA, and Application for Gene Delivery. Bioconjugate Chemistry 21 (11):2110-2118. doi:10.1021/bc100334t

14. Yoshimura T, Hasegawa S, Hirashima N, Nakanishi M, Ohwada T (2001) Anchoring and bola cationic amphiphiles for nucleotide delivery. effects of orientation and extension of hydrophobic regions. Bioorganic \& Medicinal Chemistry Letters 11 (22):2897-2901. doi:http://dx.doi.org/10.1016/S0960$\underline{894 \times(01) 00563-7}$ 
15. Farhood H, Bottega R, Epand RM, Huang L (1992) Effect of cationic cholesterol derivatives on gene transfer and protein kinase $C$ activity. Biochimica et biophysica acta 1111 (2):239-246

16. Gao X, Huang L (1991) A novel cationic liposome reagent for efficient transfection of mammalian cells. Biochemical and biophysical research communications 179 (1):280-285

17. Berchel $M$, Lemiègre $L$, Trépout $S$, Lambert $O$, Jeftić J, Benvegnu $T$ (2008) Synthesis of unsymmetrical saturated or diacetylenic cationic bolaamphiphiles. Tetrahedron Letters 49 (52):74197422. doi:http://dx.doi.org/10.1016/i.tetlet.2008.10.073

18. Halter M, Nogata Y, Dannenberger O, Sasaki T, Vogel V (2004) Engineered Lipids That Cross-Link the Inner and Outer Leaflets of Lipid Bilayers. Langmuir 20 (6):2416-2423. doi:10.1021/la035817v

19. Hutter T, Linder C, Heldman E, Grinberg S (2012) Interfacial and self-assembly properties of bolaamphiphilic compounds derived from a multifunctional oil. Journal of Colloid and Interface Science 365 (1):53-62. doi:http://dx.doi.org/10.1016/j.jcis.2011.08.057

20. Moss RA, Fujita T, Okumura Y (1991) Dynamics of a bolaamphiphilic lipid in a bilayer liposome. Langmuir 7 (11):2415-2418. doi:10.1021/la00059a001

21. Gu Q, Zou A, Yuan C, Guo R (2003) Effects of a bolaamphiphile on the structure of phosphatidylcholine liposomes. Journal of Colloid and Interface Science 266 (2):442-447. doi:http://dx.doi.org/10.1016/S0021-9797(03)00649-0

22. Rethore G, Montier T, Le Gall T, Delepine P, Cammas-Marion S, Lemiegre L, Lehn P, Benvegnu T (2007) Archaeosomes based on synthetic tetraether-like lipids as novel versatile gene delivery systems. Chemical Communications (20):2054-2056. doi:10.1039/b618568a

23. Lainé $C$, Mornet $E$, Lemiègre $L$, Montier $T$, Cammas-Marion $S$, Neveu $C$, Carmoy $N$, Lehn $P$, Benvegnu T (2008) Folate-Equipped Pegylated Archaeal Lipid Derivatives: Synthesis and Transfection Properties. Chemistry - A European Journal 14 (27):8330-8340. doi:10.1002/chem.200800950

24. Drescher S, Meister A, Blume A, Karlsson G, Almgren M, Dobner B (2007) General Synthesis and Aggregation Behaviour of a Series of Single-Chain 1, $\omega$-Bis(phosphocholines). Chemistry - A European Journal 13 (18):5300-5307. doi:10.1002/chem.200601866

25. Heinze M, Brezesinski G, Dobner B, Langner A (2010) Novel Cationic Lipids Based on Malonic Acid Amides Backbone: Transfection Efficacy and Cell Toxicity Properties. Bioconjugate Chemistry 21 (4):696708. doi:10.1021/bc9004624

26. Dittrich M, Böttcher M, Oliveira JSL, Dobner B, Möhwald H, Brezesinski G (2011) Physical-chemical characterization of novel cationic transfection lipids and the binding of model DNA at the air-water interface. Soft Matter 7 (21):10162-10173. doi:Doi 10.1039/C1sm06124k 
27. Paiva D, Martin-Molina A, Cardoso I, Quesada-Perez M, Pereira MD, Rocha S (2013) The effect of a fluorinated cholesterol derivative on the stability and physical properties of cationic DNA vectors. Soft Matter 9 (2):401-409. doi:Doi 10.1039/C2sm27236a

28. Crook K, Stevenson BJ, Dubouchet M, Porteous DJ (1998) Inclusion of cholesterol in DOTAP transfection complexes increases the delivery of DNA to cells in vitro in the presence of serum. Gene Ther 5 (1):137-143

29. Jain N, Goldschmidt V, Oncul S, Arntz Y, Duportail G, Mély Y, Klymchenko AS (2012) Lactoseornithine bolaamphiphiles for efficient gene delivery in vitro. International Journal of Pharmaceutics 423 (2):392-400. doi:http://dx.doi.org/10.1016/j.ijpharm.2011.12.026

30. Tamura M, Kochi J (1971) Coupling of Grignard Reagents with Organic Halides. Synthesis 1971 (06):303-305. doi:10.1055/s-1971-35043

31. Popov M, Linder C, Deckelbaum RJ, Grinberg S, Hansen IH, Shaubi E, Waner T, Heldman E (2010) Cationic vesicles from novel bolaamphiphilic compounds. Journal of Liposome Research 20 (2):147-159. doi:10.3109/08982100903218900

32. Berchel M, Mériadec C, Lemiègre L, Artzner F, Jeftic J, Benvegnu T (2009) Supramolecular structures based on new bolaamphiphile molecules investigated by small angle and wide angle X-ray scattering and polarized optical microscopy. Journal of Physical Chemistry B 113 (47):15433-15444

33. Deleu M, Damez C, Gatard S, Nott K, Paquot M, Bouquillon S (2011) Synthesis and physicochemical characterization of bolaamphiphiles derived from alkenyl $d$-xylosides. New Journal of Chemistry 35 (10):2258-2266

34. Dolle C, Magrone P, Riva S, Ambrosi M, Fratini E, Peruzzi N, Nostro PL (2011) Symmetric and asymmetric bolaamphiphiles from ascorbic acid. Journal of Physical Chemistry B 115 (40):11638-11649

35. Meister A, Weygand MJ, Brezesinski G, Kerth A, Drescher S, Dobner B, Blume A (2007) Evidence for a Reverse U-Shaped Conformation of Single-Chain Bolaamphiphiles at the Air-Water Interface. Langmuir 23 (11):6063-6069. doi:10.1021/la070029h

36. Yan Y, Lu T, Huang J (2009) Recent advances in the mixed systems of bolaamphiphiles and oppositely charged conventional surfactants. Journal of Colloid and Interface Science 337 (1):1-10. doi:http://dx.doi.org/10.1016/i.jcis.2009.04.082

37. Zhu L, Mahato RI (2010) Lipid and polymeric carrier-mediated nucleic acid delivery. Expert Opin Drug Del 7 (10):1209-1226. doi:Doi 10.1517/17425247.2010.513969

38. Dakwar GR, Hammad IA, Popov M, Linder C, Grinberg S, Heldman E, Stepensky D (2012) Delivery of proteins to the brain by bolaamphiphilic nano-sized vesicles. Journal of Controlled Release 160 (2):315321. doi:http://dx.doi.org/10.1016/j.jconrel.2011.12.042 
39. Martino S, di Girolamo I, Tiribuzi R, Angelo F, Datti A, Orlacchio A (2009) Efficient siRNA Delivery by the Cationic Liposome DOTAP in Human Hematopoietic Stem Cells Differentiating into Dendritic Cells. Journal of Biomedicine and Biotechnology. doi:10.1155/2009/410260

40. Fletcher S, Ahmad A, Perouzel E, Heron A, Miller AD, Jorgensen MR (2005) In Vivo Studies of Dialkynoyl Analogues of DOTAP Demonstrate Improved Gene Transfer Efficiency of Cationic Liposomes in Mouse Lung. Journal of Medicinal Chemistry 49 (1):349-357. doi:10.1021/jm0507227

41. Eliyahu H, Joseph A, Schillemans JP, Azzam T, Domb AJ, Barenholz Y (2007) Characterization and in vivo performance of dextran-spermine polyplexes and DOTAP/cholesterol lipoplexes administered locally and systemically. Biomaterials 28 (14):2339-2349. doi:10.1016/j.biomaterials.2006.09.001

42. Kim JY, Choung S, Lee EJ, Kim YJ, Choi YC (2007) Immune activation by siRNA/liposome complexes in mice is sequence- independent: Lack of a role for toll-like receptor 3 signaling. Molecules and Cells 24 (2):247-254

43. Ramesh R, Saeki T, Templeton NS, Ji L, Stephens LC, Ito I, Wilson DR, Wu Z, Branch CD, Minna JD, Roth JA (2001) Successful treatment of primary and disseminated human lung cancers by systemic delivery of tumor suppressor genes using an improved liposome vector. Mol Ther 3 (3):337-350

44. Templeton NS, Lasic DD, Frederik PM, Strey HH, Roberts DD, Pavlakis GN (1997) Improved DNA: liposome complexes for increased systemic delivery and gene expression. Nature Biotechnology 15 (7):647-652

45. Nuraje N, Bai HY, Su K (2013) Bolaamphiphilic molecules: Assembly and applications. Progress in Polymer Science 38 (2):302-343. doi:Doi 10.1016/J.Progpolymsci.2012.09.003

46. Rädler JO, Koltover I, Jamieson A, Salditt T, Safinya CR (1998) Structure and interfacial aspects of self-assembled cationic lipid-DNA gene carrier complexes. Langmuir 14 (15):4272-4283. doi:Doi 10.1021/La980360o

47. Bataillard P, Gardies F, Jaffrezicrenault N, Martelet C, Colin B, Mandrand B (1988) Direct Detection of Immunospecies by Capacitance Measurements. Anal Chem 60 (21):2374-2379. doi:Doi 10.1021/Ac00172a011 